\title{
Model of the System of Detection, Development and Support of Technical Talent of Children and Youth
}

\author{
Olga Vasilevna Shatunova
}

Kazan Federal University (Yelabuga Institute), Russia, Yelabuga, Kazanskaya St., 89

Doi:10.5901/mjss.2015.v6n6s3p122

\begin{abstract}
The purpose of the article consists in representation of creation experience of the work system with technically gifted children and youth in conditions of the university. The author has used criterion approach to definition of types of talent. The methods of the research of the problem of technical talent development are the synthesis of the best pedagogical experience, supervision, questioning of teachers and a conversation with them. Innovative projects are presented and were analysed: The children's university, the intellectual children's camp "InteLLeto" for gifted children, "Mechta", the summer physical and mathematical school, the Center of the educational robotics functioning on the basis of the Yelabuga institute of the Kazan federal university. The paper describes the experience of holding competitions and contests on technology among school students gained by engineering and technological faculty. It has shown that participation of school students in such projects and actions promotes not only to the development of their talent but also forms their steady interest to technical and design types of the professional activity that in turn allows them to get a profession demanded at the modern labor market. It is pointed out that there is an objective need of special training of a teacher which would promote formation and development by teachers the necessary professional competence for the successful work with gifted school students. The development and support of technically gifted students at the university are promoted by their participation in the design-technology bureau "Evrika"'s work which is directed on formation of skills of research and design-technology activity, on deepening and fixing the knowledge gained in the course of theoretical training, on practical mastering of a methodology and means of designing and development of a car - and motorequipment, tools, facilities, devices, machines, educational visual manuals and also technologies of their production.
\end{abstract}

Keywords: technical talent, technical skills.

\section{Introduction}

Technical education is becoming today one of the most priority and wanted at the labor market. The long existing stereotype of legal and economic professions appeal had a bad effect on the number of experts of the engineering directions and also the staff at the domestic industrial enterprises. Many young people do not still like to go the higher education institutions on the technical preparation directions. However, as many experts and researchers noted, the technical higher education institutions are capable to provide the growing intellectual potential of Russia in the near future. That is why one of the primary tasks, that today the education system has, must be the purposeful and systematic work on involvement of technically gifted children and youth to design and engineering and creative in order exactly this activity will become for them the vital sense.

In "Working concept of talent" (Working concept of talent, 2006) has given the following definition: "Talent is the systemic developing during the life quality of mentality which determines a possibility of achievement of high, uncommon results by the person in one or several kinds of activity in comparison with other people". This definition allows considering that the success achievement of the person demands the development of talent during the life. The B. M. Teplov's statement who wrote the following: "talent is a qualitative and peculiar combination of skills on which a possibility of achievement of great or little success in the performance of this or that activity depends" proves it. The definition says that talent does not guarantee the success in any activity but just give "a construction material" for its achievement. And if the person will not develop talent given by nature than after a while it is possible to find out that predisposition to a certain activity will become less expressed, and further development of skills will demand the considerable investments or in general will become impossible.

\section{Literature Review and Problem Statements}

The problem of talent is considered in science from various positions: with philosophical, biological, and also 
psychological and pedagogical ones. Philosophers study talent of the person within common problems of realization of the person's skills. Biology considers the problem of talent according to genetics putting on the first place natural-science components of the gifted person development. In psychological science the emphasis is placed on the analysis of mentality and creative abilities. Pedagogical concepts generally connect the manifestation and development of talent with the separate developing conditions of the sociocultural and educational environment. For example, according to the concept of the American scientist J. Renzulli, talent represents a combination of three characteristics: the mental abilities (higher the average level), creativity and persistence (motivation focused on a task) (Renzulli, 1983). The scientist says that to gifted children it is necessary to refer not only those who surpasses contemporaries on all three key parameters, but also those who shows the high level at least to one of them. Besides, this concept considers the knowledge (erudition) and the favorable environment (Savenkov, 2000).

Some scientists (Babayevo, 1997; \& Savenkov, 2000) in their researches consider talent as a certain dynamic characteristics. They think that talent is not a static (constant) personal indicator but constantly developing potential. Here we can already point out the problem of talent development or, speaking differently, the problem of the potential development of the personality of each child. This aspect is the most productive in pedagogical relation exactly for this reason it is intensively developed in the number of pedagogical researches.

The development of talent is always the result of difficult interaction of heredity (natural inclinations) and the social environment mediated by the activity of a child (game, educational, labor). The own activity of a child and also psychological mechanisms of the self-development of the personality, which are the cornerstone of formation and realization of his talent, have a special part (Merzon et al., 2013; \& Merzon et al., 2014).

Thus, talent is a multilateral but complete phenomenon. A gifted child must have not only certain genetic inclinations, but also the environment (the family, the school, contemporaries, etc.) has to promote the development of his personal qualities.

A variety of demonstrations of talent, its dependence on age, organization of the educational process at school and features of child-rearing in the family have led to allocation of the following criteria for definition of types of talent (Working concept of talent, 2006):

- on demonstration width - general and special talent;

- according to the type of the preferred activity - intellectual, academic, creative, art, psychomotor (sport), design, leader (organizing), etc.;

- $\quad$ on a demonstration form - theobvious and hidden (not shown);

- on formation degree: potential and actual talent;

- on age features of demonstration - early talent and late talent.

To the listed criteria of talent V. I. Panov adds such criterion as "the intensity of demonstration" (Panov, 1998). According to his point of view, on degree of the intensity of demonstration of talent it is possible to allocate children who show the increased readiness for training, gifted, high-gifted, solely or especially gifted (talents and child prodigies) children.

All gifted children possess the number of personal characteristics which distinguish such children from their conditionally "normal" contemporaries. Researchers of children's talent mark out various features of gifted children. For example, as distinctive features of gifted children Yu.Z. Gilbukh points the following characteristics: early demonstration of the high informative activity and inquisitiveness, the speed and accuracy of performance of intellectual operations, formation of skills of the logical thinking, richness of the active dictionary, the speed and originality of verbal associations, the expressed installation on creative performance of tasks, development of the creative thinking and imagination, possession of the main components of an ability to study (Gilbukh, 1991).

The German expert in the field of training of gifted children K.A. Heller allocates such personal characteristics of gifted children as high mental abilities, outstanding creative abilities, abilities to fast assimilation and outstanding memory, intellectual curiosity and aspiration to knowledge, high personal responsibility, conviction in own efficiency and independence of judgments, the positive I-conception connected with an adequate self-assessment (Heller, 1989).

The works of many Russian researchers point out the number of similar characteristics. So, A.I. Savenkov refer to features of the mental development of gifted children the following: the informative requirement, the supersensitivity to problems, a tendency to problems of divergent type, the originality and flexibility of thinking, an ease of ideas generation, an ability to forecasting, the high concentration of attention, an excellent memory, a social autonomy, a tendency to the competitive spirit, a good sense of humour, etc. (Savenkov, 2000).

A tendency of children to work, as N. S. Leytes fairly writes (Leytes, 2003), is also a factor of their talent. The capable but few diligent children have little chances to develop their talent than contemporaries who want to work have. There is the fact fact that great people are big toilers. In effect, a tendency to work is a component of talent. 
Thus, in psychology and pedagogical science there are various approaches to understanding of types of talent. The developers of "Working concept of talent" (Working concept of talent, 2006) along with others mark out intellectual talent, and they subdivide it into different types depending on the subject content of the activity. According to this point of view we can refer technical talent to this type. As a rule, speaking about technical talent the matter is about the abilities directed on understanding, the analysis and modeling of technical processes, the design and the analysis of mechanisms.

It is considered to be that a child has technical abilities if he is interested in mechanisms and machines, he can repair something, uses old details for creation of new hand-made articles or toys, designs, think about essence of this or that invention. Usually the technical thinking and technical awareness are peculiar to such children.

Unfortunately, there is not a lot of domestic researches on a problem of identification, development and psychology and pedagogical support of technically gifted children and youth. At different times such scientists as P. N. Andriyanov, A.N. Bogatyrev, V.A. Gorsky, T.V. Kudryavtsev, V.A. Molyako, Ya.L. Ponomarev, V. G. Razumovsky, I.S. Yakimanskaya and others have dealt with the issues of development of technical abilities.

A. Anastazi and S. Urbina mark out the following abilities which can be referred to the technical: psychomotor, spatial, mechanical ones (Anastazi, Urbina, 2007).

\section{Methods of Research Abilities}

The main objectives of competitions in robotics are:

- the attraction of the trained pupils to innovative, scientific and technical creativity in the field of robotics;

- the promotion of robotics and LEGO designing as a subject matter;

- the formation of new knowledge, abilities and competences by the trained pupils in the field of innovative technologies, mechanics and programming.

The next main direction of the work of the Yelabuga institute of the Kazan federal university on identification, development and support of technical talent of school students is the organization and conducting on the basis of engineering and technological faculty of competitions on technology. Such competitions as "Constructive labor of school students", "Young skilled worker", "Competition of projects on technical work", in which more than 300 pupils of 5-11 grades of educational institutions take part, are annually held.

The competition "Constructive labor of school students" is traditionally held in autumn, and the competitions "Young skilled worker" and "Competition of projects on technical work" are held in spring as the result of creative work of school students in a half-year. Participants of competitions compete with each other in theoretical, practical and creative rounds. They are given an opportunity to prove themselves in testing on various technologies, to show the abilities in processing of different types of materials (metal, wood, plastic, fabric, etc.) and also to show the creative abilities in registration and presentation of products.

The main objectives of these competitions are:

- $\quad$ the identification and encouragement of the gifted trained pupils;

- the support to the trained youth in professional self-determination;

- the promoting of technological education among the trained pupils;

- the research of an intellectual and creative potential of pupils in the educational area "Technology".

Competitions on technology, as the school students note, are one of the most difficult but at the same time very interesting competitions. They demand hard training and laborious work. In order to take prize-winning place in such competition, a child needs to make many physical and intellectual efforts and also to involve all the creative potential. In other words, a child has an opportunity not only to show his talent, but also to develop it.

The questioning which is carried out among the teachers who prepared participants of this competition in 2013 showed that all respondents (100\%) are interested in the development of abilities of pupils and it must affect the results of their work with technically gifted school students (Shatunova \& Sergeeva, 2014). Our long-term supervisionb show that among teachers of technology it is seldom possible to meet the person who is indifferent to his work. As a rule, they are creative, active, loving children people.

To the question about by what methods and ways it is possible to develop pupils' talent, $78 \%$ of teachers have answered that they are participation in competitions and contests on technology. The same number of participants of poll considers that it is a method of projects. $60 \%$ of teachers consider that the development of gifted school students is promoted by their research activity, and $56 \%$ of teachers believe that participation in various exhibitions also develops children and teenagers' talent.

However, as practice shows, there is not enough just a desire to work with gifted school students, the modern 
teacher needs to possess certain professional competences on this area. To the question "Do you possess sufficient competences for the development of technical school students' talent?" $33 \%$ of respondents have answered negatively. It means that there is an objective need of special training of the teacher which would promote formation and development by teachers the necessary professional competence for successful work with gifted school students.

Also during the questioning we found out on what specialties and directions of preparation winners and prizewinners contets and competitions on technology usually go to study after the leaving school. The teachers have noted that about $80 \%$ of such pupils choose technical specialties and directions of preparation. This fact testifies that the involvement of school students to participation in contests and competitions on technology promotes formation at them of an interest to the equipment, various technologies, design and design activity. Among higher education institutions in which the former participants of the Interregional competition "Constructive labour of school students" now study it is possible to note such prestigious higher education institutions of Russia as the Moscow aviation technological university of K.E. Tsiolkovsky, St. Petersburg State University of technology and design, the Kazan federal university and others.

And the teachers who are actively engaged in the development of school students' technical talent it is possible to judge a successful cooperation of teachers of engineering and technological faculty of the Yelabuga institute of the Kazan federal university according to the quantity of the taken prizes at a regional stage of the All-Russian contest on technology. From the total number of the teachers who prepared the winners and prize-winners of the regional contest on technology in $201356 \%$ of teachers took part with pupils in the competition "Constructive labour of school students", in 2014 there were $40 \%$ of such teachers. Besides, at the final stage of the All-Russian contest of school students on technology already for three years the number of winners and prize-winners includes the school students of the Republic of Tatarstan participating in the competition "Constructive labour of school students".

It should be noted here that in the Republic of Tatarstan there are a lot of talented school students. In 2015109 young inhabitants of the republic became the winners and prize-winners of various All-Russian school contests (in 2014 the number of them was 73). On this indicator Tatarstan takes the third place in the country conceding only to Moscow and St. Petersburg. The republic achieved such results thanks to the realization of a republican strategy of "Kilächäk" ("Future") the main objective of which is staff and scientific technological support of the innovative development of the Republic of Tatarstan, formation and satisfaction of need of the personality for development and knowledge acquisition.

The experience which is available in the higher education institution in the organization and holding competitions on technology allows to claim that participation of school students in similar actions promotes not only the development of their talent, but also forms their steady interest in technical and design types of the professional activity that in turn helps them to get a profession demanded at the modern labor market.

One more direction of the higher education institution work on development and support of technical talent is the activity of the student's design-technology bureau "Evrika". Students' work in the bureau is directed on formation of skills of research and design-technology activity, on deepening and fixing the knowledge gained in the course of theoretical training, on practical mastering of a methodology and means of designing and development of a car - and motorequipment, tools, facilities, devices, machines, educational visual manuals and also technologies of their production. Members of the student's design-technology bureau are engaged in such types of engineering activity as designing, production and assembly of details, knots and mechanisms of various technical objects.

\section{Conclusion}

The development of students' technical talent is considerably promoted by harmonious interaction of the higher education institution with employers and representatives of a real sector of economy among whom there are a lot of the largest domestic and foreign enterprises. The increased terms, deepening of the contents educational and the work practice is already planned. We continue to involve skilled experts in conducting classes adapting the taught disciplines for the real life. From the most widespread directions of the joint activity of the Yelabuga institute of the Kazan federal university and employers are distinguished:

- the practical training of students on real workplaces;

- the expansion of a range of educational services of the higher education institutions demanded at the labor market;

- the definition of requirements to the quality of specialists' training, recently the examination of the main educational programs developed by the structural divisions of higher education institutions according to requirements of the Federal state educational standards of higher education concerning the inclusion in the main educational program of additional competences taking into account an opinion of the leading regional employers; the development and reviewing of an educational and program documentation; 
- giving by employers' representatives and experts the classes for students of higher education institutions, including lecture courses, seminars, master classes, business games, practical works, etc.;

- a participation of employers in total state certification of graduates;

- the training of teachers on real workplaces;

- the professional development of employers' representatives at the higher education institution;

- a participation of employers in scientific and practical conferences, educational projects, scientific sessions, days of science in higher education institutions, etc.;

- a design integration (joint scientific researches, opening of basic chairs of the higher education institution at the enterprises of employers, creation of the joint small knowledge-intensive companies, etc.);

- an employment of graduates;

- the organization and joint participation in the regional advisory boards and associations for the purpose of the improvement of the content of professional education taking into account the needs of concrete regions, etc.

Thus, at the Yelabuga institute of the Kazan federal university the Model of the system of detection development and support of technical talent of children and youth which can be considered as the effective mechanism of preservation and enhancement of Russian intellectual potential is realized.

\section{References}

Anastazi, A. \& Urbina, S. (2007) Psihologicheskoe testirovanie. SPb.: Piter. pp. 688.

Babaeva, Yu.D. (1997) Dinamicheskaya teoriya odarennosti // Osnovnye sovremennye konceptsii tvorchestva i odarennosti. M.: Molodaya gvardiya, pp. 275-294.

Gilbuh, Yu.Z. (1991) Vnimanie: odarennye deti. M.: Znanie. pp. 79.

Leites, N.S. (2003) Vozrastnaya odarennost i individualnye razlichiya: izbrannye trudy. M.: Izd-vo psihologo-socialnogo instituta; Voronezh: Izd-vo NPO «MODEK». pp. 464.

Panov, V.I. (1998) Nekotorye teoreticheskie i prakticheskie aspekty odarennosti // Prikladnaya psihologiya. №3. pp. 33-48.

Rabochaya kontseptsiya odarennosti / Edited by D.B. Bogoyavlenskaya, V.D. Shadrikov (2006) M.: Akademiya, pp. 98.

Savenkov, A.I. (2000) Odarennye deti v detskom sadu i shkole. M.: Akademiya. pp. 232.

Heller, K.A. (1989) Perspectives on the diagnosis of giftedness // German Journal of Psychology. No 13. pp. 140-159.

Merzon, E.E., Panfilov, A.N., Panfilova, V.M. \& Shterts, O.M. (2013) The Multifactor Pedagogical Model of the Development of Giftedness in Children and Youth // Middle-East Journal of Scientific Research. No 16 (12). pp. 1694-1699.

Merzon, E.E., Shterts, O.M., Shatunova, O.V. \& Panfilov A.N. (2014) Sex-age dynamics of development of technical giftedness signs /I Life Science Journal. No 11 (6). pp. 539-542.

Renzulli, J.S. (1983) Guiding the gifted in the pursuit of real problems: The transformed role of the teacher // The Journal of Creative Behavior. No 17 (1). pp. 49-59.

Shatunova, O.V. \& Sergeeva, A.B. (2014) Academic competitions and Technology Olympiads as a means to identify and develop endowments of school students. Life Sci J; 11(11): 380-383. 